\title{
The Role of Audit in Detecting Errors in Financial Statements
}

\author{
Agim Kastrati \\ Universiteti Europian i Tiranës, Blv. "Gjergj Fishta", Nd. 70 H 1, Tiranë \\ akastrati7@hotmail.com
}

\begin{abstract}
The main objective of the audit is to detect potential errors in the client's financial statements. This study aims to identify faults that are detected by auditors during auditing of financial statements. Ten audit firms are interviewed, in various cities of Kosovo, for the purpose of collecting data for errors found during the audit of the financial statements of their clients, for the period January-December 2012. The data obtained show that through the implementation of various audit procedures are found different type of errors which occur for various reasons ranging from lack of experience of clients personnel, insufficient knowledge of accounting principles and negligence. Data from this study provide empirical support to previous studies. Researches undertaken by Hylas and Ashton (1982) have shown that the audit affects the detection of errors in the financial statements, which have occurred for various reasons. The study provides knowledge that audit helps companies to eliminate errors which affect the accuracy and reliability of financial statements.
\end{abstract}

Keywords: Audit, financial statements, disclosure of errors

\section{INTRODUCTION}

The main objective of the audit of financial statements is to provide an opinion regarding the financial statements if they present fair, in all material respects, the financial position of the client.

The condition of being real financial statements should be free from material misstatement. The auditor's task is to implement audit procedures necessary to verify the accuracy of financial statements items to be convinced that these statements are free of material misstatement. To achieve the goal, the auditor plans his work based on the evaluation of the functioning of internal control, information available on the functioning of the client and the auditor's professional judgment based on the experience of the auditor in his professional work with clients.

Knowledge that takes in conversation with client staff also serves as a starting point where to find potential errors in the client's financial statements. All these serve the auditors to determine audit procedures and techniques in order to obtain adequate information about whether the financial statements are free from material misstatement. In this paper are analyzed errors found by auditors in various cases that are reported from audits of economic entities.

Our questionnaire has been designed so that, for all errors detected, reported initial events that affected the discovery of the error and the area of the financial statements where the error was found. Also, are reported audit procedures that are used in case of error detection and in any case described the cause of the error happened?

Hylas \& Ashton (1982) in their study found that auditor' expectations, based on prior audits of the clients and their discussions with client personnel, helps to the detection a significant number of errors in financial statements. Chen \& Leitch (1999) and Dzeig (1994), concluded that the analytical procedures suggests the auditor, in terms of finding errors in the client's financial statements. Austen, Eilifsen \& Messier (2003), in their study have concluded that the analytical procedures, discussions with staff and expectations from previous years, have significant impact on the appearance of errors in financial statements. 


\section{OBJECTIVES OF THE STUDY}

The first objective is to establish empirical evidence about events that affect the detection of errors in financial statements and to create empirical evidence about audit procedures that are applied in the case of detection of errors in financial statements.

Reasons that have influenced the occurrence of errors in financial statements, focusing in unintentional mistakes.

To contribute to the general awareness of the public about the role of auditing in enhancing the reliability of audited financial statements.

\section{RESEARCH QUESTION AND HYPOTHESIS}

The hypotheses of this study are based on the findings of previous studies in this area as well as our experience in the field of study. These hypotheses are as follows:

\section{$\mathrm{H} 1=$ Expectations from prior audits and analytical review have an important role in detection of the errors? \\ H2 = Personnel problems have a direct impact on the errors in financial statements?}

Based on these hypotheses is designed questionnaire which was sent to 10 (ten) local audit firms in Kosovo for audits of 2012, in which auditors were asked to respond to the questionnaire prepared in connection with mistakes detected during the audit.

Through the questionnaire was asked to give answers to these sets of questions:

a) Initial event that affected the discovery of the error,

b) The auditing procedures applied in that case,

c) The audit areas in which the errors occurred,

d) The cause of the error, and the

e) The size of the client, the area in which it operates, and other records connected with the client.

Six audit firms responded to our request that reported by 54 audits conducted, in which 32 of them are found errors, reported 68 errors detected in the financial statements of their clients.

Audited entities of which are reported errors are from different areas and are shown in the following figure:

Fig. 1

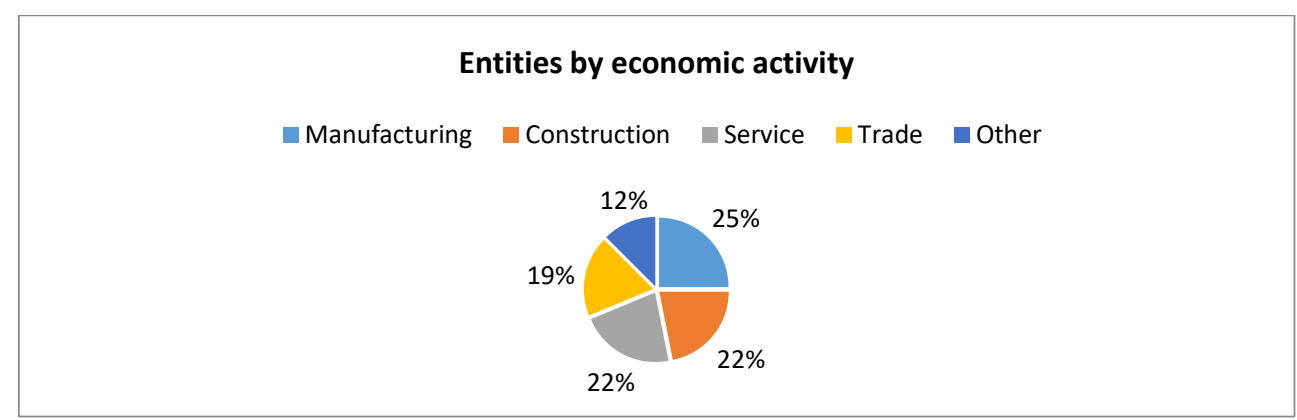

From the audited entities 8 (eight) of them are engaged in the manufacturing field, 7 (seven) of them are engaged in construction, 7 (seven) in services, 6 (six) in trade and other areas 4 (four) of them. 


\section{ANALYSIS, DATA EXPLANATIONS}

Audit procedures, initial events or circumstances that help auditors to detect errors in the financial statements are classified as follows: (1) expectations from previous audits, (2) analytical procedures, (3) information from the client, (4) test of detail, (5) confirmations and (6) other procedures.

The auditor's professional judgment is based on his experience and knowledge that has in the profession as well as the expectations of the findings from previous years. This thing helps the auditor, to be oriented where can found errors in financial statements.

Analytical procedures are audit procedures that are made in the audit planning stage and at later stages which give information where can found potential errors. These procedures relate to compare the area of the current financial statements with the previous year as well as financial data comparison with the average of industry in which the client operates.

The information from the client from conversations with staff, regarding business performance, problems faced during work etc. give signals for potential errors.

Factors that have contributed to the appearance of errors in financial statements are divided as follows: (1) the insufficiency of professional knowledge in accounting, (2) estimate or misjudgment, (3) Accrual errors, (4) inadequate internal control, (5) technical errors, (6) other problems.

The first category includes errors made about the lack of professional knowledge of staff and insufficient professional personnel engaged in accounting. This has been influenced by the limited knowledge of accounting principles and wrong application of accounting policies in the preparation of their financial statements. In this category are included also the mistakes that occurred because of negligence of staff engaged in accounting jobs.

The second category of errors has to do with errors in assessment or judgment, has to do with errors on valuation of receivables, settlement of inventory and contingent liabilities.

Accrual errors in the end of the year, where some transactions are not presented in the period in which they occurred. Here, first of all it comes to prepaid expenses which must be distributed in the period incurred.

Errors due to the lack of adequate control procedures and reviews dealing with errors in reconciliation, reviews of old account balances for collectability, etc.

Technical errors related to errors in various calculations made by staff employed in accounting jobs. Errors reported by the audits are presented in Table 1 and the 54 audits have reported a total of 68 errors.

\section{Table $1 \quad$ Material errors reported}

\begin{tabular}{|c|c|c|c|c|}
\hline Nr. & Number of audits reporting & Number of Errors & Cumulative & $\%$ \\
\hline 1 & 22 & 0 & 0 & $\begin{array}{l}40 . \\
74\end{array}$ \\
\hline 2 & 16 & 1 & 16 & $\begin{array}{l}29 . \\
63\end{array}$ \\
\hline 3 & 6 & 2 & 12 & $\begin{array}{l}11 . \\
11\end{array}$ \\
\hline 4 & 4 & 3 & 12 & $\begin{array}{l}7 . \\
41\end{array}$ \\
\hline 5 & 3 & 4 & 12 & $\begin{array}{l}5 . \\
56\end{array}$ \\
\hline
\end{tabular}




\begin{tabular}{|l|l|l|l|l|}
\hline 6 & 2 & 5 & 10 & 3. \\
& & & & 70 \\
\hline 7 & 1 & 6 & 6 & 1. \\
& & & & 85 \\
\hline & 54 & & 68 & 100. \\
& & & & 00 \\
\hline
\end{tabular}

In 16 cases (29. 63\%) of the audits are reported by an error for each audit. Six of the 54 audits reported by two errors, which represents $11.11 \%$ of the total reported audits.

Six audits have resulted with two errors for each audit, which represent $11.11 \%$ of the total reported audits.

Four audits have resulted with three errors for each audit, which represent $7.41 \%$ of the total reported audits.

There are six reported audits with 4-6 errors, which represent $11 \%$ of the total of reported audits, while $22(40.7 \%)$ reported not finding errors.

Initial events, circumstances that help auditors to detect errors in the financial statements are presented in the following table:

Tab. 2

Initial Events

\begin{tabular}{|r|l|c|c|}
\hline Nr. & \multicolumn{1}{|c|}{ Initial Event } & Errors & $\%$ \\
\hline 1 & Expectations from prior years & 22 & 32.35 \\
\hline 2 & Analytical review & 18 & 26.47 \\
\hline 3 & Discussions with the client personnel & 5 & 7.35 \\
\hline 4 & Test of detail & 12 & 17.65 \\
\hline 5 & Confirmations & 4 & 5.88 \\
\hline 6 & Other procedures & 7 & 10.29 \\
\hline & Total & 68 & 100.00 \\
\hline
\end{tabular}

Expectations from prior years and analytical review detected 40 errors or 58.82 percent of all errors.

From the above we can conclude that the first hypothesis is confirmed:

H1 = Expectations from prior audits and analytical review have an important role in detection of the errors

Table 3 Distribution of errors reported by audit area and industry

\begin{tabular}{|c|c|c|c|c|c|c|c|c|}
\hline $\begin{array}{l}\mathrm{N} \\
\mathrm{r} .\end{array}$ & Audit area & $\begin{array}{l}\mathrm{Nr} \text { of } \\
\text { errors }\end{array}$ & $\%$ & $\begin{array}{l}\text { Industri } \\
\text { al \% }\end{array}$ & $\begin{array}{l}\text { Constr } \\
\text { uction } \\
\%\end{array}$ & $\begin{array}{l}\text { Service } \\
\%\end{array}$ & Trade $\%$ & $\begin{array}{l}\text { Other } \\
\%\end{array}$ \\
\hline
\end{tabular}




\begin{tabular}{|l|l|l|l|l|l|l|l|l|}
\hline 1 & $\begin{array}{l}\text { Property, plant and } \\
\text { equipment }\end{array}$ & 9 & 13.24 & 8.33 & 14.29 & 20.00 & 12.50 & 20.00 \\
\hline 2 & Inventory & 5 & 7.35 & 16.67 & 0.00 & 0.00 & 12.50 & 0.00 \\
\hline 3 & Accounts receivable & 8 & 11.76 & 12.50 & 9.52 & 10.00 & 12.50 & 20.00 \\
\hline 4 & Cash & 11 & 16.18 & 8.33 & 14.29 & 30.00 & 25.00 & 20.00 \\
\hline 5 & Revenue & 12 & 17.65 & 20.83 & 19.05 & 10.00 & 12.50 & 20.00 \\
\hline 6 & Prepaid expenses & 7 & 10.29 & 12.50 & 14.29 & 0.00 & 12.50 & 0.00 \\
\hline 7 & Income taxes & 8 & 11.76 & 8.33 & 14.29 & 10.00 & 12.50 & 20.00 \\
\hline 8 & Purchase cycle & 6 & 8.82 & 12.50 & 9.52 & 10.00 & 0.00 & 0.00 \\
\hline 9 & Contingent liabilities & 2 & 2.94 & 0.00 & 4.76 & 10.00 & 0.00 & 0.00 \\
\hline & Total & 68 & 100.00 & 100.00 & 100.00 & 100.00 & 100.00 & 100.00 \\
\hline Number of errors gabimeve & & & 24 & 21 & 10 & 8 & 5 \\
\hline Number of companies & & & 8 & 7 & 7 & 6 & 4 \\
\hline
\end{tabular}

Three audit area included 32 (47 percent) of the 68 errors detected. These areas were revenue cycle (12 errors), cash (11 errors) and property, plant and equipment (9 errors).

Among industrial companies 20. 83 percent of errors detected occurred in the revenue cycle and 16.67 percent in inventory area.

Table 4 Distribution of errors by audit area and company size

\begin{tabular}{|c|c|c|c|c|c|}
\hline \multirow[b]{2}{*}{ Nr. } & \multirow[b]{2}{*}{ Audit area } & \multirow{2}{*}{$\begin{array}{l}\text { Number of } \\
\text { Errors }\end{array}$} & \multicolumn{3}{|c|}{ Company size } \\
\hline & & & $\begin{array}{l}\text { Revenue < } \\
2 \text { milion } €\end{array}$ & $\begin{array}{l}\text { Revenue } 2 \\
4 \text { milion } € €\end{array}$ & $\begin{array}{l}\text { Revenue } \\
4 \text { milion } €\end{array}$ \\
\hline 1 & Property, plant and equipment & 9 & 4 & 3 & 2 \\
\hline 2 & Inventory & 5 & 1 & 2 & 2 \\
\hline 3 & Accounts receivable & 8 & 3 & 2 & 3 \\
\hline 4 & Cash & 11 & 4 & 4 & 3 \\
\hline 5 & Revenue & 12 & 5 & 4 & 3 \\
\hline 6 & Prepaid expenses & 7 & 3 & 2 & 2 \\
\hline 7 & Income taxes & 8 & 2 & 3 & 3 \\
\hline 8 & Purchase cycle & 6 & 3 & 1 & 2 \\
\hline \multirow[t]{4}{*}{9} & Contingent liabilities & 2 & 0 & 1 & 1 \\
\hline & Total & 68 & 25 & 22 & 21 \\
\hline & Number of companies & 32 & 10 & 11 & 11 \\
\hline & No-error companies & 24 & 9 & 8 & \\
\hline
\end{tabular}


The table shows that larger companies have a smaller number of errors in proportion to medium and small size companies, with an approximate number of audits.

The table also shows that errors involving the revenue, cash and property, plant and equipment tended to occur more frequently in smaller companies, while errors involving accounts receivable and income taxes tended to occur more frequently in larger companies.

\section{Table $5 \quad$ Errors detected by various initial events}

\begin{tabular}{|l|l|l|l|}
\hline Nr. & Factor identified & $\begin{array}{l}\text { Nr. } \\
\text { errors }\end{array}$ & $\%$ \\
\hline 1 & Insufficient accounting knowledge & 21 & 30.88 \\
\hline 2 & Judgment error & 8 & 11.76 \\
\hline 3 & Accrual error & 14 & 20.59 \\
\hline 4 & Inadequate internal control & 12 & 17.65 \\
\hline 5 & Mechanical error & 7 & 10.29 \\
\hline 6 & Other & 6 & 8.82 \\
\hline & Total & 68 & 100.00 \\
\hline
\end{tabular}

The lack of professional knowledge of the staff represents the largest percentage of the causes of the errors found by the auditors $(30.88 \%)$, followed by accrual errors that were reported in 14 cases $(20.59 \%)$ and Inadequate internal control reported in 12 cases (17.65\%).

As stated above, we conclude that the second hypothesis is confirmed:

H2 = Personnel problems have a direct impact on the errors in financial statements

\section{DISCUSSION}

Our results suggest that auditors' expectations of errors based on prior audits and discussions with client personnel led to the detection of 32 percent of all errors.

It may be useful to compare our results with other studies that have described certain characteristics of errors found by audits. Kinney (1979) found that results suggest that expectations from prior years were effective in signaling of errors.

Analytical procedures also have a special role in detecting the errors in the financial statements, and according to reports from audits reported they have enabled the discovery of over $26 \%$ of reported errors. Previous studies support this conclusion, so Chen \& Leitch (1999) and Dzeig (1994), have concluded that the analytical procedures give signal in terms of finding errors in the client's financial statements. Austen, Elifsien \& Messier (2003) in their study have concluded that the analytical procedures, discussions with staff and expectations from previous years, together have enabled the detection of $29 \%$ of the errors reported.

Other procedures that enable detection of errors are essential tests, which certainly should not be overlooked, in direction of potential errors in financial statements.

Regarding the causes of errors, the findings of this paper show that over thirty percent of reported errors, dealing with the lack of professional knowledge in the field of accounting. Previous studies have similar results, so Mautz, Reilly \& Maher (1979) have found that staff issues are the main causes of errors in financial statements. Austen, Elifsien \& Messier (2003) 
in their study also concluded that personnel problems such as lack of experience, not competence, negligence, etc. , have significant impact on the occurrence of errors in financial statements.

Area of the financial statements, in which are found large number of errors, is the area of revenues, followed by cash and fixed assets. Previous studies also have similar results, area of revenues is the area where most of errors have occurred. Hulas \& Ashton in the study cited above, have come to the conclusion that most of errors are detected in the area of revenues ( $16 \%$ of total errors).

\section{CONCLUSIONS / RECOMMENDATIONS}

Results of this study show that most of the audits results with finding errors in financial statements. Initial procedures which have signaled auditors, in terms of errors in financial statements, are the expectations from previous years, conversations with personnel and analytical procedures. Should not neglect the role of essential tests in detecting material misstatement in the financial statements.

Revenues represent the area where most of errors are reported and dealing with lower incomes reported. Then according to reported errors, cash and assets of customers represent the areas of reported errors.

Regarding to the causes of errors, the results of this paper show that, client personnel problems are important causes of errors in financial statement data. Client personnel problems such as inexperience, incompetence, and insufficient knowledge of accounting, are instrumental in causing of errors. As a result, are presented numerous mistakes during registration in accounting accruals.

We recommend that professional associations organize trainings for accountants of economic entities, so that the professional staffs take the necessary knowledge about accounting standards and other knowledge in the field of accounting.

We recommend the management of economic entities, to employ professional staff in accounting affairs and allow the staff participation in trainings in the field of accounting, in order to follow current developments in this area and to be continuously informed about the legislation in accounting and changes in accounting standards.

\section{References}

[1] Austen, L. Eilifsen, A. \& Messier, Jr. W. F. (2003)" Auditor detected misstatements and the effect of information technology" Institute of Accounting, Auditing and Law. Norwegian School of Economics and Business Administration

[2] Bell, T. \& Knechel, W. R. (1994) 'Empirical analyses of errors discovered in audits of property and casualty insurers', Auditing: A Journal of Practice \& Theory, 13 (Spring), pp. 84-100.

[3] Bunget, O. C. , (2009), "The role of financial auditor in detecting and reporting fraud and error" MPRA Paper No. 12888.

[4] Caster, P. , D. W. Massey, \& Wright, A. M. (2000) 'Research on the nature, characteristics, and causes of accounting errors: The need for a multi-method approach', Journal of Accounting Literature 19, pp. 60-92.

[5] Chen, Y. and R. A. Leitch (1998) "The Error Detection of Structural Analytical Procedures: " Auditing: A Journal of Practice and Theory, Vol. 17, No. 2, Fall 1998, 36-70.

[6] Eilifsen, A. \& Messier, Jr. , W. F. (2000) 'The incidence and detection of misstatements: A review and integration of archival research', Journal of Accounting Literature, 19, pp. 1-43.

[7] Entwistle, G. \& Lindsay, D. (1994) 'An archival study of the existence, cause, and discovery of income-affecting financial statement misstatement', Contemporary Accounting Research, 11 (Summer), pp. 271-96.

[8] Hylas, R. E. \& Ashton, R. H. (1982) 'Audit detection of financial statement errors', The Accounting Review (October), pp. 751-65.

[9] Kinney, Jr. , W. R. (2000) 'Discussion of "Research on the nature, characteristics, and causes of accounting errors: The need for multi-method approach"' Journal of Accounting Literature 19, pp. 93-101. 
[10] Kreutzfeldt, R. W. \& Wallace, W. A. (1986) 'Error characteristics in audit populations: Their profile and relationship to environmental factors', Auditing: A Journal of Practice \& Theory (Fall), pp. 20-43.

[11] Maletta, M. \& Wright, A. (1996) 'Audit evidence planning: an examination of industry error characteristics', Auditing: A Journal of Practice \& Theory (Spring), pp. 71-86

[12] Mautz, R. K. , Reilly, R. R. \& Maher, M. V. (1979) "Personnel Failure: The Weak Link in Internal Control" Financial Executive, pp 22-25.

[13] Wright, A. \& Ashton, R. H. (1989) 'Identifying audit adjustments with attention-directing procedures', The Accounting Review (October), pp. 710-28 